\title{
Circuit of Culture: Advocating Suicide Prevention and Eradication of Mental Illness Associated Stigma through 'Into The Light Indonesia' Campaign
}

\author{
${ }^{1}$ Daina Pratiwi, ${ }^{2}$ Abhirama SD Perdana \\ 1,2Program Studi Ilmu Komunikasi, Fakultas Humaniora, President University \\ E-mail: perdana.abhirama@president.ac.id
}

\begin{abstract}
Into the Light Indonesia is one of the most known communities that concerns about suicide intervention and the eradication stigma associated with mental illness in Indonesia. This research was analysing how Into the Light Indonesia is circulated and consumed by Indonesian through various media platforms especially social media. Circuit of culture is applied in this research in order to dig the understanding of how the meaning produced in this campaign is circulated and consumed by its audiences. There are still many people who are still not aware regarding this issues. The development of technology makes people easily receive and finding information in simple touch on their hands. Into the Light Indonesia brought this issues and successfully gained attention from its audiences by reaching 6,000 likes, 3,000 followers, published articles and invited to national and international talk shows. Into the Light Indonesia builds relationship with other communities that have the similar concerns relating to mental health. This research is applying cultural approach as the method to analyse based on each moment in the circuit of culture. This research will contribute to the literature journal of international public relation and practical significance in the related field.
\end{abstract}

Keywords: Into the Light Indonesia, Circuit of culture, Advocacy, Health Communication Campaign, Social Media

Abstrak. Into the Light Indonesia adalah salah satu komunitas yang dikenal peduli akan penyadaran intervensi bunuh diri dan pemberantasan stigma yang terkait dengan penyakit mental di Indonesia. Penelitian ini menganalisis bagaimana 'Into the Light Indonesia' diedarkan dan dikonsumsi oleh orang Indonesia melalui berbagai platform media terutama media sosial. Sirkuit kebudayaan diterapkan dalam penelitian ini untuk menggali pemahaman tentang bagaimana makna yang dihasilkan dalam kampanye ini diedarkan dan dikonsumsi oleh khalayak. Masih banyak orang yang masih belum sadar mengenai masalah ini. Perkembangan teknologi membuat orang mudah menerima dan menemukan informasi dengan sentuhan sederhana tangan mereka. Into the Light Indonesia membawa masalah ini dan berhasil mendapatkan perhatian dari khalayaknya dengan mencapai 6.000 likes, 3.000 follower, menerbitkan artikel, dan diundang ke acara talkshow nasional dan internasional. Into the Light Indonesia membangun hubungan dengan komunitas lain yang memiliki keprihatinan serupa terkait dengan kesehatan mental. Penelitian ini menggunakan pendekatan budaya sebagai metode untuk menganalisis berdasarkan setiap momen dalam sirkuit budaya. Penelitian ini 
akan berkontribusi pada jurnal literatur hubungan masyarakat internasional dan signifikansi praktis di bidang terkait.

Kata kunci: Into the Light Indonesia, Sirkuit kebudayaan, Advokasi, Kampanye Komunikasi Kesehatan, Media Sosial

\section{Introduction}

Suicide is known as one of the leading causes of death in the world. There are many considerable variants of suicide case in every country, including Indonesia. According to World Health Organization (WHO) data in 2001, Indonesia's suicide rate reached 1.6 to 1.8 people for every 100,000 people, means that there are approximately one million people died by suicide. The rate of suicide across the world reach 16 per 100,000 which increases in the past four decades and substantially increases suicide rates globally as much as $60 \%$ Though the average number of suicide cases in Indonesia was still lower compared to other countries such as Japan and China, however, the deaths occur due to suicide was 24 in 100,000 of the population. In 2006, there are about 100,000 Jakarta's people committed suicide. The factors related to common mental disorder in Indonesia such as hopelessness, insecurity, poor education, and poverty (Vijayakumar, 2004).

In 2007, Indonesian National Health in their research reported that there are approximately 1 million people who suffered a heavy mental illness and 19 million people suffered medium to mild mental disorder. Government reports that 2015 health budget is 1.5 percent of the total and 90 percent of people who want to access are not able to access to mental health services cannot due to paucity of services. Based on 2015 WHO reports, the suicide mortality rate in Indonesia was 2.9 per 100,000 of the population. The suicide Hotline in Indonesia was established in 2010 and closed down in 2014 due to ineffective in human resources and the budget, while the number of callers decreased each year. Indonesian Ministry of Health ("Layanan Hotline Bunuh Diri Sudah Tidak Aktif Sejak 2014", 2017) stated that started in 2010, there are 161 callers. There was an increase in 2013 where the number of callers increased to 267, but it drastically decreased to only 46 callers in 2014.

Until now, Indonesia does not have any such of data provided on suicide and there is no National Data for suicide rate and the reports of suicide commonly retrieved from National Police Department. WHO states that depression and suicide case rate will increase by the year of 2020. As the technology and media develops which gives to an organisation, ITL Indonesia launched an advocacy campaign and community through traditional and digital platform as its medium to advocate mental health issues, especially reducing the stigma and communicating suicide prevention through their programs. The programs are focusing more on the media education, society, cultural, and structural approaches. Through this advocacy campaign, people 
not only aware and gain knowledge, but also encourages people to do actions by participating in fighting the stigma and preventing suicide by improving health outcomes in Indonesia.

Into The Light Indonesia, as the context of this study, is a youth based community, established in 2013 that aims to campaign suicide prevention and eradicating the stigma associated with mental disorders. Currently, Into The Light Indonesia has their trained volunteers known as 'LightBringers' involving in fighting the stigma, providing physicians and health institution recommendation, education, and helping people with mental health issues and suicide ideation through peer counseling known as 'Pendamping Sebaya'. Into The Light Indonesia uses hashtags \#HapusStigma, \#PeduliSesama, \#SayangiJiwa as its motto to motivate and to encourage people to be aware of mental health issues and suicide cases in Indonesia (Into The Light Indonesia, 2013). The campaign uses digital platform such as blog and Social Networking Sites (SNS), media coverage such as talkshows and discussions as the medium tool in delivering messages to their audiences. Into The Light Indonesia also uses direct approaches, including education, building alliances with other communities and training in many education institutions. The campaign is produced to influence the public to be aware, and taking an action in the moment of consumption.

This study analyses how Into The Light Indonesia's advocacy in reducing the stigma and suicide prevention is produced, circulated, and consumed by Indonesian and the policy makers and achieved its objective by applying Circuit of Culture as the theoretical framework. This research also provides explanation about the meaning, value, and cultural context of ITL Indonesia shared that will be reflected in five moments in the Circuit of Culture by Stuart Hall. This research contributes to literature of public relations or further research about health communication campaign strategy.

\section{Literature Review}

In the process of communicating the message to the audiences, public relations practitioners establish their certain forms of representation, known as public relations tactics. Each tactic consists of symbols, they are both visual and verbal, spoken and unspoken, visible and invisible. How those text and visual chosen, produced, and interpreted are influenced by culture, as it is one essential part in meaning making process. In order to achieve the goals and objectives, public relations practitioners need to consider the strategy and develop tactics so it can be successfully absorbed by the target audiences. By applying public relations on the circuit of culture, the public relations practitioners not only create production but also infuse the cultural values, as audiences receives and the way of delivering message depends on the culture where the action take space. Cultural constructs do not affect PR practices; they are the essential part of public relation practices (Curtin \& Gaither, 2007, p.12). 


\section{Circuit of Culture}

Basically, everything has meaning, it depends on how we define, present, and socially construct them. A society sharing meaning system depends on the culture we live in. In his book "Representation: Cultural representations and signifying practices", Hall explained that culture is a most difficult in human and social concept and there are many ways to make definitions of it. Williams and Hall (1997) defined culture is an endless process where the meaning is produce $\mathrm{d}$, circulated, consumed, commodified, and negotiated in society. The meaning shared can change overtime and through use, the meanings also take part in different social groups with different connotation. The meaning of a term can be variants not only in a country, but also within a culture itself.

In 1997, Hall and a group of scholars at Britain's Open University, created circuit of culture as a combination of each scholar's focus (du Gay, Hall, Janes, Mackay \& Negus, 1997). In the creation of circuit of culture, the meanings are produced into several different sites and circulated, forming a cultural circuit in the process and practices. The circuit of culture consists of five moments; regulations, production, representation, consumption, and identity).

Figure 1. The Circuit of Culture (from Curtin \& Gaither, 2007, p.38)

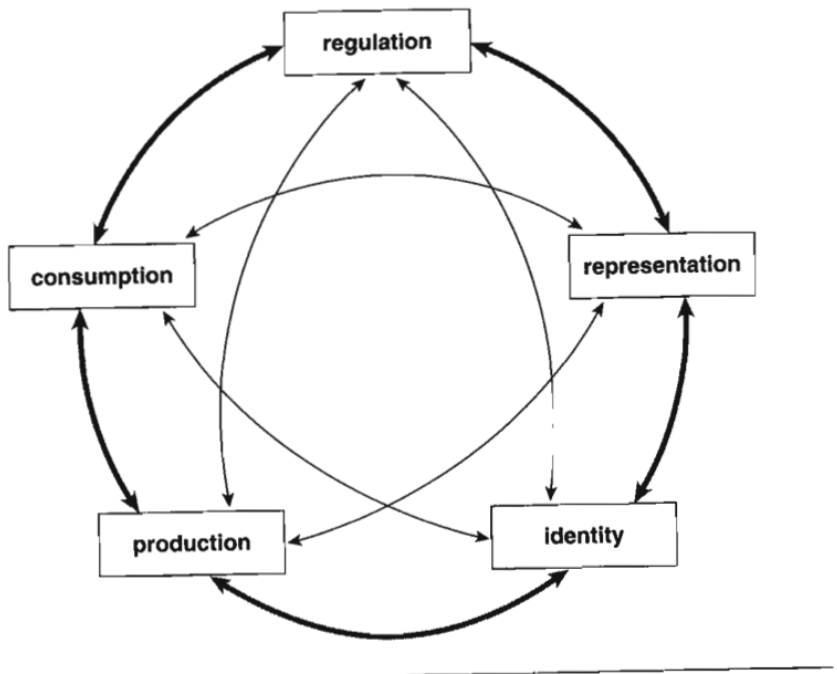

Each moment is endlessly circulated and interrelating to each other to create meaning, both to a particular moments or to the whole. Each moment works synergistically, forming a cycle without a start line or the end of the circuit. The circuit of culture model has been applied for further use in public relations practices, such as WHO's Eradication of Small Pox campaign (Curtin \& Gaither, 2017) and 'Beat Rugby' campaign by Adidas.

\section{Regulation}

Regulation is a set of controls on cultural activity, ranging from legal controls, which can be in a form of laws, policies, and the system or structural of a country to local controls and hidden regulations such as norms, belief, and 
common sense in a culture. In the moment of regulation, the meanings shared is from where it emerges, governing what is acceptable or correct. Regulations exists in order to maintain the system, protect, or improve a nation or society. The meanings could contribute to the how the rules, norms, and convention by adapting them to the existing governed society. It also helps the public relations practitioners in producing the context in which the activity takes place. Despite the regulations helps in maintaining the society to still get on track, regulations is also an influence of how a society view things differently and sometimes, in a negative way. For example, stigma rooted in a certain culture.

\section{Stigma by Goffman (1963)}

In a simple definition, stigma is a sign of disgrace that set an individual apart from others (Byrne, 2000). It can be in a form of prejudices, discrimination, and social humiliation to a certain issues, social attributes, ethnicity, religion, or even physical and social problems. According to Link and Phelan (2001), There are many different types of stigma, one of them around society is stigma of mental illness, where the subject of the stigmatisation find difficulties to overcome. Based on previous research by Lestari \& Wardhani (2015) in "Stigma and Management on People with Severe Mental Disorder with "Pasung", a person who has heavy mental illness is always associated with demon possession or lack of faith in a religion and will be bind 'pasung' to restrain the patient. This also applies in other cases where an individual who are diagnosed having mental illness become the subject of stigmatisation and will choose to hide themselves instead of seeking medical supports, even though mental illness is curable and not a spreading disease.

\section{Production}

Production is where the creators of the cultural product create and infuse the meaning into the product or the message they will deliver, which is also called encoding. The meaning produced will be distributed through many ways and with variety of medium. In the moment of production, the producers' plan is adapting to the culture of the environment and executing it to where the action take place. In Mackay's (1997) focus, the meaning is produced based on how the creators express themselves in, making use of it, how they want their message consumed or appropriate cultural 'things', which make it valuable when we reflect them into everyday life. For example, Indonesian McDonald's launched 'nasi uduk', an Indonesian steamed rice cooked in coconut milk dish as their menu as the result of McDonald's adaptation from Western fast food restaurant with variants of Indonesian culinary which gives a Indonesian cultural value to the daily life of consumers.

\section{Representation}

In the moment of representation, the cultural product form an object and the meaning encoded in that form. Curtin and Gaither (2007) explained that people encode the meaning is not based on from the object itself, but from how 
it is socially constructed. The producers created the meaning into text or visual, as the form of their message to be delivered to their target audiences through variety of communication channels. The connection between representation and culture is both are about sharing meaning. People who shares the same language will also share the same meaning when they see some words in their language because through the language, people 'make sense' of things in where the meaning is created and exchanged. In here, thinking and feeling Language is the key repository of cultural values and meanings (Hall, 1997)

In order to communicate the meanings to the audiences, the producers must be able use the same linguistic code, or speak the same language, or having cultural common sense. Language in this sense, is not only the written or the spoken ones, but it is based on elements from what it represents for, like what we want to say, to express an idea or concept within the message we deliver. For example, in Indonesia, when people eat in a fast food restaurant such as McDonalds. In some western countries, McDonald is represented as one of common, cheapest fast food restaurant that every people can afford, while in Indonesia, McDonald's represents as a fine fast food restaurant with a good place to hangout, which some Indonesians still consider McDonald's as an expensive chain fast food restaurant.

\section{Consumption}

Consumption is the process of decoding the messages, or when the information are received by the audiences Consumers, commonly known as the target public, will bring their cultural values and their own semantic network when they decode and decode the meaning in exchanging communication activities. Consumers make their own meaning and adapt those meanings into the product or issues into their own daily life where they live according to their own way.

According to du Gay (1997), although the meaning created by the producers provided possibilities, they meaning only can be actualised in the moment of consumption. Though the meanings are meant to be consumed in the end, it does not mean that the moment of consumption as the end of the process of circuit of culture. The moment of consumption itself forms a new meaning accrue to the forms of artifact to produce and to put into the new kinds of uses based on the audiences itself, as both consumers and creator at the same time. The meanings consumed will be interpreted in accordance the way they interpret them and the cultural values they possessed.

\section{Identity}

Identity is the construction of meaning in representing cultural product. The identity gives an individual a place in society, informing who they are and how an individuals relate to others in the world they live. People produce a product in order to be identified as what they want to represent, to be known for, or remember for, depending on how it is consumed. An identity can be 
either positive of negative, it is based on what on the creators needs them what they want to be known for and the identity they want to implement in the culture where the action takes place. The characteristic, values, and meanings behind a cultural product affects the identity the producers created for their audiences. Those elements create an identity attached to a product, that the audiences consume and remember what is the product known for; is it a good product? What is this campaign known for?. The moment of identity can be seen in example of the rainbow flag, which is commonly used in campaigning LGBT since rainbow color symbolises the LGBT itself. Until now, the producers who concerns about LGBT will create a product and used rainbow color to represent a LGBT campaign, since people already know the symbol of LGBT is always associated in rainbow color.

There are always many variants of meaning in every culture. Meaning changes over time and society create meaning through the culture they experience. In public relations term, circuit of culture is a paradigm from RACE (Research, Action, Communication, and Evaluation) is used to gain understanding about cultural meaning. In the development of technology, audiences are no longer easily being injected by the information of the media, they react, filter and response towards the message they received.

Circuit of culture as the medium between the producer and consumers, both in sharing meaning. However, in public relations, the practitioners need to define the meaning they produced in cultural activity. Circuit of culture focuses on five meanings, each of them constructs different meaning they deliver and circulated to each other. In Indonesia, the application of cultural study in public relations practices is still less often used, however it does not make the circuit of culture not effective in analysing the current situation, which makes this research have a contribution to relevant study in Indonesia.

\section{Health Communication}

Health communication is communication involving advocacy and improvement of individuals or public health for outcome situation (Schiavo, 2007). In order to achieve goals, a practitioner need to aim for improving health outcomes by sharing information and influence the individuals and communities. It encouraged people to do action. Health communication has the important role in creating the receptive and comfortable environment where the information can be delivered, consumed, discussed by the audiences in accordance to the producers of campaign intended to. In order to do that, it requires an in-depth understanding about a culture, such as the needs, belief, history, taboo, lifestyle, attitudes, and social norms of all key communications. It also requires the communication is based on messages that audiences can create the meaning easily. This is supported by the definition of communication defined by Pearson and Nelson (1991), that communication as the "process of understanding and sharing meaning" In sharing meanings, the individuals of 
community, changing behaviours, and to support and sustain change are the key attributes to health communication .(as cited in Schiavo, 2007).

Health communication intervention has been used for many years by researchers, experts, and nonprofit organisation, companies, to promote the the goals of oriented product related to health. There are many key elements in health communication; audiences centered, research based, multidisciplinary, strategic, process oriented, cost effective, creative in support and strategy, audience and media specific, relationship building, and behavioural and social change. In health communication, audiences is not a passive, but they response, reach, and finding what is culturally appropriate towards the message they decode. In advocating the behavior change, one public relations practitioners need to understand the condition of the environment they live in. Targetting opinion leaders and key influencers (family members, health educators or providers) can contributes and support the programs of a health communication campaign. Educating the target regarding health issues and how to address them is one step of a long term process, which also need theoretical flexibility in order to accommodate the needs of intended groups or audiences.

\section{Health Communication Campaign}

Communication campaign are everywhere, and it is impossible to avoid them in this new era. The emergence of social media, where the information can be accessed easily. Communication campaign consists of coordinated messages or other communication effort that already design in order to achieve goals. A campaign is an effective tool to advocate for health, as if health communication is applied for strategies to inform that influences health. In order to achieve the target, health communication campaign must apply the strategy to influence the audiences through the designed message in health related field in the area. Through health communication, the messages needs to be consistently disseminated, in accordance to the strategy and tactics of public relations practices.

\section{Media Convergence Theory}

In the past recent years, the rapid growth of technology has brought the huge improvement in almost everything. Everyone can get the information in easily just by clicking and touching from their technology, everything that were previously separated comes together. The emergence of new media has change the game from old media. Media is considered as the most powerful tool, not only to provide information, but also in shaping and influencing people. From old media to new media, it demonstrates that media is developing through the time. The old media somehow does not fade, but the function can change by adapting to new technology innovations, while media convergence contains how whole technological shift and the flow of media in people's life (Jenkins, 2006). 
People consume media differently, and it always changed from the time to time. The way people consume information is based on the culture, and the development of technology influences the culture of people consume media. The culture can change overtime as the technology develops. However, the old media is not simply gone in one day. The old media were once considered new in their era, slowly become old and people will slowly leaving the old media to new media. People use new media, such as social media, since it is a worldwide media which not only provides information, but also for daily life interaction. In this modern era, the amount of people who use social media is increasing and the most internet activities are dominated by young adults (Lenhart, Purcell, Smith \& Zickhur, 2010). New media involved 'computerisation' or needs the technology in message distribution. It can be in a form of social media, web television or alternative web TV, or internet. People can do many things in their hands in reaching their audiences, especially campaign. The use of digital campaign is really popular in this new era, people who have internet access can easily access and get the information from the new media platforms, especially social media.

Media convergence involves participatory culture and collective intelligence. According to Jenkins (2006), in participatory culture, people as both producers and consumers, they interact to each other and exchanging information; giving, receiving, and digging information through the media. People has different way in interpreting and delivering the information, both through media or directly. Some information can become the popular or the most topic if the information is often consumed by people in a short time. While the collective intelligence is how individuals collect information. The collected information can be used as a strong tool in everyday's interaction (Jenkins, 2006)

\section{Methodology}

This research analyses how Into the Light Indonesia as a suicide prevention community advocates the eradication of stigma regarding mental health issues and preventing suicide through their programs and messages to its audience, which is mainly teenagers in Indonesia. The research questions the process of circulation from how Into the Light Indonesia is produced, represented, its identity, and how it is consumed by people. ITL Indonesia has been operating for almost five years and has been building alliance with other communities to promote the awareness about mental health issues in Indonesia. Into the Light Indonesia gained attention in National talkshows, seminars, and International talk in Australia-Indonesia Center in 2018. 


\section{Qualitative Methodology}

Qualitative research is a method of research which claims to describe life worlds 'from inside and $\mathrm{ou}^{\prime}$ from the point of view of the people who participate. Qualitative research seeks to contribute to a better understanding of social realities and drawing the conclusion in the process, meaning patterns structural features. Qualitative research tend to collect data on the site of the participants experiences, stories, and their issues under the study.

Qualitative research requires procedures which produce descriptive data in the form of words written or spoken by the people and behavior observed, concerning more with the explanation of the relationship, related to the ideas, perception, opinions, and beliefs which cannot be measured by numbers (Bogdan and Taylor, 2015). In Qualitative research, the researchers collect the data by examining documents, observation, or interviewing participants. Qualitative research has strong orientation to daily events and knowledge of those under the investigation.

The paradigm applied in this research is interpretivism. Interpretivism is a type of research method which includes the human element because it relies on how the researchers interpret the information obtained from the study itself. The interpretivism views reality as something subjective and based on meanings and understanding. The goal of the research is understanding, rather than making predictions. Interpretivist researchers don't consider the knowledge generated from the research to be permanent but accept it as relative to the time, context or culture in which the study was conducted. Researchers are more interactive and participatory in their research studies.

The primary data collection methods used in the interpretivist approach include interviews and observations of the subjects. In this research, the researcher applied interview as the primary data collection method. Primary data are the specific information collected by the person who is conducting the research. The result is obtained during the observation to be the primary data that used to answer the problem, the questions. The researcher chose the most reliable source, the producer of the campaign itself, Benny Prawira as the Head Coordinator of ITL Indonesia. The categorising of data, the researcher uses manual, structured coding (Saldana, 2009). In this research, the informant will be asked several questions that is already structured adapting from each moments of circuit of culture and the articulations of each moment.

Secondary data are the data that have been collected by readily available from other resources. The researchers in here must locate the data sources that may be useful given their own research problem and they must be able to retrieve the relevant data, since it is important to evaluate how well the data meet the quality requirements of the current research and the method of qualified analysis. Secondary data are cheaper and quickly obtainable than the primary data and also may be available when the primary data cannot be obtainable at all. Secondary data, such as online sources were obtained when 
the researcher conducted used additional data to complete the research data. Photos or pictures, text or document, photos shared from their social media or published articles related to ITL Indonesian and mental health issues to support the research.

By applying circuit of culture in this research can help to examine the meaning and how the meanings are circulated. As the current model applied in International Public Relations practices; where all function of public relations embraces through economic model by placing the culture at the centre (Curtin \& Gaither, 2007). The process of meaning making reflected in each moment will circulate and interrelating to each other. Circuit of culture as the paradigm of RACE in public relations, Comparing to public relations model such as RACE or PENCIL model, circuit of culture model can adapt the time change, as meanings can change over time, and there will be new emerging culture in the future. In RACE model, audiences are submissive as they receive information, while in circuit of culture, audiences interpret, create, and shape the meanings they consumed, stimulating them to take actions towards the meaning they decode (Curtin \& Gaither, 2007). Circuit of culture is considered as the most suitable model to be utilised in analysing and examining how advocacy works in a campaign.

In collecting data, it is important to pay attention to ethical issues. In this research, the following ethical consideration, advocated by Robson (2002) were applied to this study so that this study does not violate any ethical regulations that are in place for academic exercises. He accepted to participate and allowing the researcher.

Regardless, as long as the researcher was able to determine even perceived ownership on the part of content contributors, the researcher made every effort to gain consent for use of all visual and textual material. Instead, all consent was recorded through voice recorder, and gained from data involving text, pictures. The researcher chose to follow in the footsteps of Pearce (2011) who "adopted the standard ethical practice of maintaining study subjects' and informants' anonymity through the use of pseudonyms for individuals, groups, and locations".

The researcher did not intend to ask the participants about personal information. Yet, certain distinguishing characteristics did present themselves naturally through the research process. The informants shared the information only related about ITL Indonesia. It is already stated in the letter of consent which is already agreed by both parties.

Into the light Indonesia is chosen because it is one of the Indonesian community that concerns about the mental illness issues in Indonesia and has been operating for more than four years. However, after several discussions and evaluation, ITL Indonesia closed down the peer consultation on 16th April 2018 and their social media from 22th April to 22th May 2018 for more new advocacy programs approach. This happened a week after the researcher 
conducted the interview with the campaign producer on 8th April 2018. ITL Indonesia realises that the function of a mental health community is not for substituting the professional health treatment, but in increasing awareness of the the participation to access the mental health services and change the perspective of the society regarding mental health issues. People still are not aware the importance of mental health issues. This research is applying Circuit of Culture as theoretical framework to dig more understanding about how ITL Indonesia deliver their meaning through their messages and consumed by the audiences, especially from various cultures in Indonesia. This research also will contribute to the journal of International Public Relations and the practical significance for an effective public relations strategy or approach to the related fields in a certain culture.

\section{Findings and Discussion}

In this section, the result of this research is analysed by utilising circuit of culture as theoretical framework in order to identify and dig more understanding of how each moment in into the Light Indonesia's campaign is reflected, circulated, and interrelated, forming a whole complete cultural circuit in the meaning making process. The findings will also show the result of Into the Light Indonesia when their target audiences consume the message which will influence the process of advocacy in reducing the stigma and preventing suicide by social intervention through their programs.

\section{Regulation}

The factor causing an individual committing suicide is complex, but the major cause is mostly because of depression. In Indonesia, the number of people who commits suicide significantly increasing each year. Started in 2010, the number of people who commits suicide reached 5000 victims in a year and increased into 10.000 victims in 2012. Recently in 2017, Eka Viora as the Head of Indonesian Association of Doctor Specialist Mental Health, there are approximately 9 million people diagnosed with depression ("9 Juta Orang Mengalami Depresi", 2017). As the head coordinator of Into the Light Indonesia, Benny Prawira explained that people who suffer depression and suicide ideation, is ranging from 13 years old to adulthood. The number will increase every year as it also attacks younger people. In this case, Benny indicates that the due to the stigma, they hide themselves instead of seeking professional help, because having mental illness is considered a shame.

\section{Government's Involvement in Eradicating the Stigma}

The suicide cases in Indonesia is already concerned by the government, in Indonesian Criminal Code of Procedures, in the article of 304 regarding the regulation where the person does not take any action to prevent the victim from committing suicide. The number of people who committed suicide are still uncertain since there are still no national suicide rate obtained from the local 
sources, since it is usually mixed with other death cases. The Indonesian suicide rate data usually only obtained from WHO reports, stated that there are 1.6 to 1.8 in every 100.000 people. In 2014, the previous Ministry of health, dr. Nafsiah Mboi Sp.A, MPH (www.depkes.go.id, 2014) asked all health institution to implement the four national programs to stop the stigma and discrimination towards people with mental illness, involving prohibition to discriminate and doing stigmatisation towards people with mental illness, practicing acceptance, social and medical supports, and health promotion in order to educate people about the importance of mental health in Indonesia. It is still applied until now under Prof. Dr. dr. Nila Moeloek SpM, the current Minister of Health of Indonesia.

Government already concern about this issues. It is stated in constitution law of Republic of Indonesia 1945, the article of 20,21, 28, line (1), and article 34 line 3 regarding the mental health, where people with mental illness are equals and treated like the same standard as normal human being. The previous Indonesian Ministry of Health, In article 4 line 1, it is also stated about mental illness intervention by promoting mental health by attempting to help in reducing stigma, treating people with mental illness equally, and increasing role and acceptance towards mental health issues. Indonesian Ministry of Health ("Layanan Hotline Bunuh Diri Sudah Tidak Aktif Sejak 2014", 2017) stated that started in 2010, there are 161 callers. There was an increase in 2013 where the number of callers increased to 267 , but it drastically decreased to only 46 callers in 2014.

\section{The Hidden Regulations - Society's Perspective and Cultural Norms}

However, the obstacles of this issues are in the implementation and society's view about mental illness is still considered negative in Indonesia. There are things to consider, such as the human resources, the budget, and the administration process, since it is a long term plan. Benny added that most of the people who contacted ITL Indonesia sometimes struggle to seek medical help due to difficulties in accessing health facilitations, although if they live in the city where it is supposed to be easier to find mental health facilitation. Other factors are fear of rejection, humiliation, and disgrace to a particular family or culture.

In 2007, According to Human Right Watch (2011), that there were approximately one million people who suffer mental illness and attempting suicide. The government involvement concerning these issues, the budgeting spent for mental health is only 1 percent of whole national health budget and according to the total allocation for whole national health is only given approximately 5 percent from Indonesian state budget until 2017 ("Dana Kesehatan Tetap 5 Persen si APBN 2017", 2016). The total budget for health in 2018 does not increase, into 111 trillion in total, but the percentage of budget is still stuck in the number of 5 percent (Ministry of Finance of Republic Indonesia, 2018). 
Furthermore, the anticipation of people is still lacking regarding this concern. Some areas may deal with mental illness with social support or in a negative way, such as rejection, discrimination (Goffman, 1963). Other than epidemiologic data issues, the legislation and health budgeting become things to consider. The treatment gap, stigma, and discrimination experienced by people who suffer mental illness and depression become unnoticed issues yet it is already spread out in Indonesia (Ridlo, 2017).

The culture of people also influence the way the people view this issues. Benny claimed that some culture or people may associate mental illness with spiritual belief or religion, For example 'Pulung Gantung', where people commit suicide by hanging in Gunung Kidul, resulting Gunung Kidul has the highest suicide rate in Java (National Geographic, 2017). Other cases include some Indonesian still practice 'Pasung' or physical restrain for people who suffer heavy mental illness as the last alternative way due to lack of anticipation at the beginning. As the result, ITL Indonesia created the campaign adapting to the regulations in the country but also from Into the Light's initiative towards the condition of Indonesia.

\section{Production}

ITL Indonesia is established as the product of the community, focusing on the suicide prevention. The purpose of this campaign is to reduce the stigma and to prevent suicide by communicating the mental health awareness and social intervention for mental problem outcomes. The campaign has its own motto \#HapusStigma, \#PeduliSesama, \#Sayangijiwa. The campaign is mainly intended for teenagers, policymakers or government, and public in Indonesia. The reason behind this campaign is because suicide is also happening in Indonesia as it is already reflected in the moment of regulations, however there is still lack of approach and education regarding this issues. In this situation, Into the Light established a peer counseling programs called Pendampingan Sebaya, for online consultation and recommendation for nearby professional help (Into the Light Indonesia, 2013).

In the moment of production, Benny as the Head coordinator of ITL Indonesia created ITL Indonesia for public, but it is mostly intended for teenagers. ITL Indonesia has two kinds of programs on reducing the stigma and other focuses, which is planning for more advocacy programs regarding the suicide prevention. As the producer, Benny advocates for the access and better quality of health services through this campaign, by producing the messages from the contents, seminars, building relationship with private sector, and a logo that supports the campaign itself. There is always a try and error in executing the program. ITL Indonesia created the vision and mission adapting from the regulations and the current situation of Indonesia. To support its vision, ITL Indonesia create the logo as the form of the representation of their campaign, as the community of hope because it is creating positivism to Indonesian youth generation. in its message, Benny stated that ITL Indonesia 
wants to deliver the meaning 'empowerment' and 'encouragement' to do action for the people who suffers from mental illness and depression. The campaign also advocated for the change of society's negative perspective associated with mental illness.

\section{Targetting Opinion Leaders with Health Education}

In order to obtain the cooperation in some areas, Into the Light Indonesia team would talk to opinion leaders for media educations and to organise the workshop, training, or advocacy program planning. The opinion leaders mostly came from the health or mental health educators, motivators, religious leaders, and community leaders. Currently, ITL Indonesia has been cooperating with Jakarta School of Theology educators in , the largest Schizophrenia community leader, Bagus Utomo, and many psychological experts in campaigning this issues. In a certain areas with different culture, the producer, acknowledged that culturally, Indonesia still believe that mental illness still can be recovered by spiritual way or getting them closer to their belief or religion. In this moment, Into the Light Indonesia in the campaign also create meaning through their message, adapting from Indonesian culture and belief in educating their audiences from various backgrounds.

As the technology develops, Into the Light is using both direct approach and new media as their communicative tool to spread their message to the wide range of audiences. In new media, Beside programs, ITL Indonesia produce the meaning in a form of text and visual. In text, Into the Light Indonesia produced contents in various social media platforms and posting announcement such as seminars about suicide intervention, workshop, and education in many different places such as Suicide Potrayal in Our Media in Gadjah Mada University, Luangkan Satu Menit Mengubah Satu Kehidupan, Mental Health Fest 2017, Sambung Nyawa, many more. Benny added that he created Into the Light Indonesia as a form of building positivism, as he mentioned hope, arise, social support for the people who suffer emotional breakdown. Into the Light Indonesia also published articles related to mental health issues, by relating to the current issues happening in International area for the audiences in order to gain knowledge and awareness.

The obstacles in this moment is when Benny stated, they are lacking donators in campaigning this concern. ITL Indonesia utilised their own self financing, by selling merchandise, helping the other communities fundraising. There is still resistance of the society, since in advocating suicide and mental health issues is still lack of anticipation, although many people concerns about this issues. They still do not know about the real complex cause of suicide and how to overcome when they face it. However, Benny stated that he will not give up in advocating this issue. He is aware that that the culture influences the dynamic risk of suicide attitude and action. For example, if someone who suffers depression in a family cultures that put family value as the first priority 
and he failed to achieve something, he will put his family to shame. The patient would likely to commit suicide to protect the family reputation.

\section{Representation}

In the moment of representation, Into the Light as one of campaign that focuses on suicide intervention. Into the Light Indonesia produced the logo, illustrating the tail of the phoenix with a yellow light color, with text "Into the Light". Benny explained in the making of the logo, he put the phoenix from the ancient mythology creature, representing the eternal life cycle. The phoenix is a creature from the Greek Mythology that symbolises renewal or resurrection (Ancient Origins, 2014). It is supported by the vibrant yellow color which represents the light itself. According to Cerrato (2012) in his book "The Meaning of Colors", yellow color is often associated with intellectual, freshness, and joy. If compared to the producers interpretation of yellow color and Cerrato, both of them create the meaning of optimism and building positivism. The logo hasn't changed since it's firstly established. People who are aware of mental health will recognise the logo from its name and the illustration represented in the campaign. This campaign involves digital campaign since the producers of this campaign spread their product into many varieties of old media, such as Radio or television (TV) and new media, including alternative television (Youtube) and social media (Facebook, Twitter, Blog, and Instagram).

Benny also relates the logo into the the campaign as the campaign where an individual who suffers depression and having mental illness can be cured and still have the chance to continue living their life. ITL Indonesia acknowledged that in the process of recovery, it does not always have to be in medical method, there are other recovery methods, such as the spiritual or recovery based on belief or religion.

Figure 2. Into the Light Logo

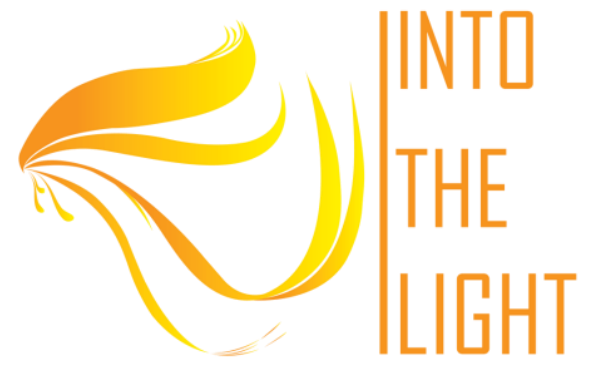

In the moment of representation, the emergence of the new media also applied to reach wider audiences, primarily for Indonesian youth. Although, ITL Indonesia also utilises the direct approach to the public in order to create the stronger influence and to educate their public to take actions, one of them in a form of intervention for the person who suffer mental illness or the family and relatives of the patient. It is already stated in its vision, Into the Light advocates for the better environment and social intervention for suicidal people in 
Indonesia. In this new era, youth nowadays not only passively receive information, but they also become active audiences, can be reached and stimulated by the new media. New media as the channels of communication used as an effective tool to encourage the target audience to participate in ITL Indonesia community. ITL Indonesia, as a health campaign not only involve encouraging behavior changes, improving an individual mental heath and focus on encouraging people's behavior towards people who stigmatised within society more broadly (Foster, 2017).

\section{Consumption}

The rapid growth of technology, SNS influences the most to the dissemination of meaning produced by ITL Indonesia as the community that campaigns suicide prevention and reduction of stigma associated with mental health in Indonesia. By the new media, Into the Light has broadened its way in campaigning the issues to wider range of audiences. Using SNS is considered as one effective way to deliver the key messages, since many people, especially millennials or youth nowadays usually use SNS in their daily life. According to Linberry (2012), the participation of internet users can be stimulated through the SNS.

\section{Audience's Response to Into the Light Indonesia}

As the result of the ITL Indonesia in campaigning their message, some audiences are interested to participate in the campaign by applying to become a volunteer, attending seminars, training and education, or in a form of daily life action by recommending people to the mental health professionals. The volunteer who are interested to join ITL Indonesia reached more than 50 people before selection and from many various background. Some audiences also takes action by recovering themselves, or started to seek help from professionals immediately. They also response by sending an email as the peer counseling, means that some audiences are encouraged to recover and still have will to overcome their struggle. People as an audiences is categorized as an active audiences, and the goal is its media use (West \& Turner, Introducing Communication Theory: analysis and Application, 2010).

Figure 3. Into the Light Indonesia on Instagram

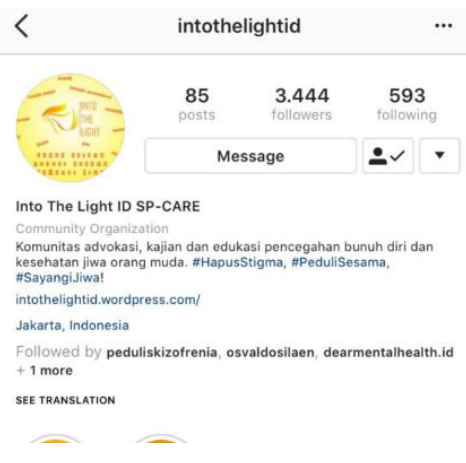


Through social media, ITL Indonesia successfully reached more than 6000 likes on Facebook, 3444 followers on Instagram, and around 400 followers on Twitter. It is not as popular as the other campaign, however ITL Indonesia successfully gained attention in International talk shows, in Australia Southeast Asia Centre and other media coverages. The community were invited to Kick Andy show, Beritagar, and Trans7. Besides of media coverage, ITL Indonesia also appeared on Google search and recommendations results related to ITL Indonesia as one of the biggest community which concerns about the Indonesian condition that lack of anticipation in mental illness issues.

According to the result, ITL Indonesia successfully gained attention from the society who has the same concern. ITL Indonesia allied with other communities such as Komunitas Peduli Skizofrenia Indonesia, the largest schizophrenia care community by Bagus Utomo that has similar focus which is reducing the stigma associated with mental illness, the others are Bipolar Care Indonesia, Mother Care Indonesia, Get Happy Yuk Indonesia, and many more. Those communities built alliance in advocating the mental health awareness and mental health outcome situations.

Although ITL Indonesia is not a direct help or consultation like any other health institution, ITL Indonesia focuses on the campaign itself and building relations across sector. The producers did the research which is already stated in their vision and mission. Due to the absence of the Suicide National Hotline, Into the Light decided to established peer counseling. Benny added that some people who reached Into the Light Indonesia interpret that ITL Indonesia as the 24 hours consultation.

Although the producers try their best to encode the meanings while attempting to shape the discourse, not all production efforts ends in success. The obstacles usually happen in the moment of consumption, or where the meaning of the message are decoded by the consumers (Curtin \& Gaither, 2007). Into the Light Indonesia has some obstacles in the moment of consumption. The message encoded in the campaign is not delivered thoroughly, since some people still decode the message in different way. In the end, Benny closed the peer consultation program because at first the peer consultation was not meant to be established. Due to the high demand, ITL Indonesia established it. ITL Indonesia also received critics, especially when ITL Indonesia stated that suicide and mental health issues are not always associated with belief or religion, since Into the Light Indonesia prefer on the program to overcome the depression or suicide ideation through medical treatment.

\section{Identity}

Since in the moment of consumption, Benny indicates that the identity from the campaign is based on the identity crisis of Indonesia culture in anticipating mental health issues. Due to the difficulties to access the professional help, People identified Into the Light as the 24 hour consultation or the community that provides health services. ITL Indonesia wants to be 
recognised in bringing the 'modernisation' and adapting to cultural values, through education to some Indonesian certain societies which have highly stigmatised culture. The reflection previous moments discussed in circuit of culture shapes the meaning that makes the identity of ITL Indonesia itself.

In the moment of Identity, ITL Indonesia created the campaign to be identified as one pioneer of community that specialised in suicide intervention. As the community, Into the Light Indonesia created the meaning of positivism and providing hope for their audiences. By providing a sense of hope, unity, and socialising the eradication of stigma associated with mental illness, ITL Indonesia wants to be identified as the campaign that advocates for a better mental health outcomes and suicide intervention education to its audiences. In Indonesia, since the majority of the populations are muslims, sometimes there are many recovery methods for people who suffer mental illness will be treated in spiritual way or some people may feel better if they pray or dedicating themselves to their belief.

From the result, it shows that Indonesian society still lacks of identity in anticipating the people mental health issues, there is still lack of tolerance towards people who has mental illness. In the moment of identity in here also shows that some of Indonesian cultures have different view about suicide cases and mental health issues. ITL Indonesia already acknowledged that the spiritual method of recovery or awareness is not wrong. In this case, the producer wants to represent that there is not distinction of different belief as everyone is treated like equals.

\section{Conclusion - Completing Into the Light Indonesia Circuit}

By employing the circuit of culture in analysing this case study, it is demonstrated that the circuit of culture is important for public relations and communication practices. From the reflection of each moment, it showed that the campaign not only advocates for mental health issues, but also gives cultural values through its program in its associated discourse. By constructing the meaning in its vision, content, and messages, and providing the adaptation of psychological aspects in cultural approach in building hope and positivism for a better life for those who have mental illness, ITL Indonesia has gained attention from its target audiences. Especially, the emergence of the new media in this new era made the distribution of messages to a wide range of audiences.

The engagement that ITL Indonesia created through new media makes many people aware, and can reach wider range of audience in Indonesia, it gives more advantages for the campaign in increasing the campaign reputation and people will notice the existence of the campaign that specialised in eradication of stigma and suicide prevention. The globalisation and development of new media, especially SNS contributes many aspects to this health communication related field. 
Although ITL Indonesia applied new media as its medium to disseminate its meaning, somehow it is not enough to deliver the meaning entirely to the audiences, since it also needs direct approaches in delivering the entire messages, especially to some audiences that do not have the access to the new media. In the discussion, it shows that beside the legal control, the hidden regulations, and cultural norms, especially society's view. belief and religion view regarding suicide cases and mental health issues become key elements to consider in Indonesian context that will need to be addressed in any public communication effort.

This research also demonstrated how Into the Light Indonesia negotiated how people deal with these issues, both dedicated to people who suffer the mental illness or for the family of the patients through their programs in advocating mental health; seminars, education, training or workshop, and published posts. ITL Indonesia also gives professional help recommendation from the Pendampingan Sebaya and blog posts, especially in new underserved geographical areas. As a community, ITL Indonesia cannot compensate for the medial treatment, diagnose, or preventing disease. But it can help to advocate for change and create a change for the intended audiences and contributing in creating a favourable environment and provide support for development regarding health services and mental health education for people within its programs.

However, as one of the community that focuses in suicide intervention and stigma eradication, there are obstacles in sharing meaning with the audiences and the implementation of the change from the advocacy programs itself. There are things to consider, such as cultural nuances, traditions, values of certain culture, and geographic condition in Indonesia. Though it is a voluntary organisation, it also takes time and the budget within its practices, especially in advocating for a better quality and availability of mental health services in the whole area. In advocating this concern, a public relations practitioner needs to have the understanding what communities' need and the needs to incorporate resources engagement to participate in the development of the implementation work.

A long term result can be achieved only through process and requires participation that involves interested audiences and uses culturally appropriate action areas and communication channels (Schiavo, 2007). Limitation in this research located more on the outreach of the advocacy itself. Due to the limitation, for further reasearch, it is recommended dig the more understanding about the cultural, identity and articulation in ITL Indonesia advocacy outreach, from the audiences perspective. From this research, theorising in international public relations needs a deeper understanding about certain cultures, histories, and politics where the practice takes place. This research attempts to contribute to dig understanding about the public relations by applying cultural study, especially in this area. 


\section{References}

Byrne, P. (1997). Psychiatric stigma: past, passing and to come. Journal of the Royal Society of Medicine, 90(11), 618-621.

Brillantes Jr, A. B., \& Fernandez, M. T. (2011). Good Governance, Social Quality, and Active Citizenship: Gawad Kalinga in the Philippines. International Journal of Social Quality, 1(2).

Curtin, P. A., \& Gaither, T. K. (2007). International public relations: Negotiating culture, identity, and power. Sage.

Databoks: Anggaran Kesehatan Tetap 5 persen di APBN 2017. Retrieved from https:/ / databoks.katadata.co.id/ datapublish/2016/10/31/anggarankesehatan-tetap-5-persen-di-apbn-2017

Du Gay, P. (Ed.). (1997). Production of culture/cultures of production. Sage.

Foster, J. (2017). Mental Health Campaigns And Social Representations Theory: A Consideration. Papers on Social Representations, 26(2), 4-1.

Goffman, E. (2018). Stigma and social identity. In Deviance and Liberty (pp. 2431). Routledge.

Hall, S. (Ed.). (1997). Representation: Cultural representations and signifying practices (Vol. 2). Sage.

Hall, S. (2001). Encoding/ decoding. Media and cultural studies: Keyworks, 2.

Indonesia, R. (2009). Undang-undang Republik Indonesia nomor 36 tahun 2009 tentang Kesehatan. Lembaran Negara Republik Indonesia Nomor, 144.

Mackay, H. (Ed.). (1997). Consumption and everyday life (Vol. 5). Sage.

Lineberry, Z. X. (2012). Uses and gratifications on social networking sites: Analysis of use and value of social networking sites for three types of social capital on college students.

Liputan6 : Cegah Bunuh Diri Benny Prawira Dirikan Into the Light. Retrieved from www.liputan6.com/citizen6/read/2618449/cegah-bunuh-diribenny-prawira-dirikan-into-the-light

Lestari, W., \& Wardhani, Y. F. (2015). Stigma Dan Penanganan Penderita Gangguan Jiwa Berat Yang Di Pasung.

Link, B. G., \& Phelan, J. C. (2001). Conceptualizing stigma. Annual review of Sociology, 27(1), 363-385.

Lenhart, A., Purcell, K., Smith, A., \& Zickuhr, K. (2010). Social Media \& Mobile Internet Use among Teens and Young Adults. Millennials. Pew internet \& American life project.

Jenkins, H. (2006). Convergence Culture: Where Old and New Media Collide. New York University Press. 
Kemenkes.go.id : Tiada Kesehatan Tanpa Kesehatan Jiwa, 2017. Retrieved from http:/ / www.depkes.go.id/article/view/17100900006/menkes-tiadakesehatan-tanpa-kesehatan-jiwa.html

Kumparan : Layanan Hotline Bunuh Diri Kemenkes Sudak Tidak Aktif Sejak 2014. Retrieved from https:/ / kumparan.com/@kumparannews/layanan-hotline-bunuh-dirikemenkes-sudah-tak-aktif-sejak-2014

National Geographic, 2017: Tingginya Angka Bunuh Diri di Gunungkidul, Karena Mitos atau Depresi?. Retrieved from http:/ / nationalgeographic.grid.id/read/13308747/tingginya-angkabunuh-diri-di-gunungkidul-karena-mitos-atau-depresi?page=all

Pearce, N., \& Smith, A. H. (2011). Data sharing: not as simple as it seems. Environmental Health, 10(1), 107.

Ridlo, Ilham. (2017). Indonesia Darurat Kesehatan Mental. Retrieved from https:/ / www.researchg ate.net/publication/315754402_Indonesia_Darurat_Kesehatan_Mental

Robson, C. (2002). The analysis of qualitative data. Blackwell.

Schiavo, R. (2013). Health communication: From theory to practice. John Wiley \& Sons.

Saldaña, J. (2009). An introduction to codes and coding. The coding manual for qualitative researchers, 3 .

Taylor, S. J., Bogdan, R., \& DeVault, M. (2015). Introduction to qualitative research methods: A guidebook and resource. John Wiley \& Sons.

Tempo.co : 9 Juta Orang Mengalami Depresi. Retrieved from : https:/ / gaya.tempo.co/read/877228/9-juta-orang-di-indonesiamengalami-depresi

O'Shaughnessy, M., \& Stadler, J. (2012). Media and Society. Oxford University Press.

Vijayakumar, L. (2004). Suicide prevention: the urgent need in developing countries. World psychiatry, 3(3), 158-159.

West, R., \& Turner, L. H. (2010). Introducing Communication Theory. McGrawHill. West, R., \& Turner, L. H. (2010). Introducing Communication Theory: Analysis and Application. Mc Graw Hill.

Wirasto, R. T. (2012). Suicide prevention in Indonesia: providing public advocacy. JMAJ, 55(1), 98-104. 